\title{
ШЛЯХИ УДОСКОНАЛЕННЯ ПОРЯДКУ МИТНОГО ОФОРМЛЕННЯ ТА КОНТРОЛЮ ЯКОСТІ ВАНТАЖІВ У МОРСЬКИХ ПОРТАХ УКРАЇНИ
}

\author{
E.KALINSKY, G.TIHOSOVA, K. KLEVTSOV \\ Kherson National Technical University
}

\section{WAYS TO IMPROVE THE PROCEDURE FOR CARGO CUSTOMS CLEARANCE AND QUALITY CONTROL IN UKRAINIAN SEAPORTS}

\section{https://doi.org/10.36910/6775-2310-5283-2021-14-19}

Мета. Метою даної роботи є пошук иляхів можливих напрямів вдосконалення взаємовідносин, які виникають під час здійснення митного контролю, і розробка методів їх практичної реалізачії шляхом скорочення кількості документів у відповідності 3 міжнародними конвенціями та директивами $Є C$.

Методика. Для досліджень використовували методи аналізу та синтезу, порівняльного аналізу та синтезу інформації, абстрагування та групування.

Результати. У статті проведено аналіз стану адаптації національного законодавства до норм ЄС у сфері митного контролю на морському та річковому транспорті. Визначено основні проблеми імплементації до національного законодавства норм, визначених в Угоді про Асоціацію з СС. На основі результатів дослідження запропоновано иляхи перспективних напрямів удосконалення порядку митного оформлення i контролю якості вантажів у морських портах Украӥни з метою скорочення кількості документів та прискорення оформлення вантажів у відповідності з міжнародними конвенціями та директивами СС. Для підвищення конкурентоспроможності та економічної привабливості морських портів України пропонується запровадити електронний документообіг, скасувати комісійний контроль на борту судна, скасувати процедури при переході між портами Украӥни, скасувати хімічний контроль та спростити радіологічний та екологічний, скасувати фінансові обмеження та прискорити процедури.

Наукова новизна. Проаналізовано стан нормативно-правового забезпечення у сфері митного контролю на морському та річковому транспорті. Вперше розроблено комплекс практичних рекомендацій щзодо удосконалення порядку митного оформлення $i$ контролю якості вантажів у морських портах України.

Практична значимість. Розроблені та запропоновані рекомендації з удосконалення порядку митного оформлення $і$ контролю якості вантажів у морських портах України, 
внесені до проекту змін існуючого Порядку оформлення приходу суден у морський порт. Одержані результати можуть бути використані для прискорення оформлення вантажів та зменшення термінів перебування суден в портах.

Ключові слова. Митний контроль, митне оформлення, ввезення, нормативно-правова база, імплементація.

Постановка проблеми у загальному вигляді та ії̈ зв'язок із важливими науковими чи практичними завданнями. Підписавши Угоду про Асоціацію 3 Свропейським Союзом (СС) Україна взяла на себе зобов'язання, щодо імплементації в законодавство норм, які визначені у розділах IV та V Угоди про асоціацію. В цих розділах, зокрема, мова йшла і про зміни, що стосуються технічних бар'єрів у торгівлі та митних процедур. Україна зобов'язалася прийняти імплементаційні нормативні акти, щодо приведення національного законодавства у відповідність до двох документів:

- Конвенція про єдиний режим транзиту від 20 травня 1987 року (Конвенція NCTS (New Customs Transit System));

- Конвенція про спрощення формальностей у торгівлі товарами (Конвенція SAD (Single Administrative Document)).

Зволікання з адаптацією національного законодавства до вищезазначених міжнародних норм призводить до значних збитків вітчизняних імпортерів та експортерів. Особливо це стосується перевезення товарів у морських портах України. До цього часу, згідно з існуючими правилами, капітан судна при заході в акваторію морського порту повинен надати 23 копії різних документів. Це призводить до збільшення часу на оформлення документації. Тому актуальним $є$ питання удосконалення митних процедур та митного контролю товарів, що переміщуються морських шляхом через державний кордон України.

Аналіз останніх досліджень. У багатьох дослідженнях вітчизняних фахівців розглядалися проблеми удосконалення нормативно-правового регулювання питань здійснення процедур митного контролю та митного оформлення водних транспортних засобів та товарів, що переміщуються ними через державний кордон України [1-5]. Але в цих дослідженнях лише наводиться критичний аналіз без прикладів та практичних рекомендацій до застосування митного оформлення та контролю якості вантажів у морських портах України.

Цілі статті. На основі аналізу нормативно-правових документів, які регулюють питання здійснення процедур митного контролю вантажів в морських портах України, та результатів їх практичного застосування 
здійснити пошук шляхів можливих напрямів удосконалення взаємовідносин, які виникають під час здійснення митного контролю, і розробити методи їх практичної реалізації шляхом скорочення кількості документів у відповідності 3 міжнародними конвенціями та директивами СС.

Об'єкт дослідження. Процедури митного контролю вантажів в морських портах України.

Виклад основного матеріалу дослідження із повним обгрунтуванням отриманих наукових результатів. Правові відносини в сфері виконання митних формальностей на морському та річковому транспорті регулюються низкою наказів Кабінету Міністрів України [6-8]. Стратегія імплементації положень директив та регламентів Європейського Союзу була затверджена розпорядженням № 747 від 11.102017 p. «Про схвалення Стратегії імплементації положень директив та регламентів Свропейського Союзу у сфері міжнародного морського та внутрішнього водного транспорту («дорожньої карти»)» [9]. Розглянемо більш детально основні положення даного документу, що стосуються порядку митного оформлення та контролю якості вантажів.

Судноплавство та вантажоперевезення водним шляхом має стратегічне значення для кожної країни, що має доступ до відкритих морів. Майже 90 відсотків світової торгівлі припадає на галузь міжнародного судноплавства. Судноплавство $є$ найбільш комерційно привабливим та найменш шкідливим для навколишнього природного середовища видом перевезень.

Наша країна, як сторона міжнародних правових актів у сфері торговельного мореплавства взяла зобов'язання дотримуватися міжнародних стандартів охорони суден, портів та безпеки мореплавства. Імплементація цих нормативно-правових актів вимагає від українського уряду наявності чітко структурованої системи загальної безпеки і забезпечення безпеки мореплавства, яка має належні кадрові, організаційні та матеріальні ресурси і сучасну правову базу. На виконання цього необхідно привести національне законодавство у відповідність 3 міжнародними стандартами судноплавства.

Для забезпечення цього необхідно розробити стратегію яка б відповідала пункту 2 доповнення XVII-6 «Положення щодо моніторингу» додатка XVII «Нормативно-правове наближення» розділу IV «Торгівля і питання, пов'язані 3 торгівлею» та положенням Угоди про асоціацію між Україною, 3 однієї сторони, та Європейським Союзом, Європейським співтовариством з атомної енергії і їхніми державами-членами, з іншої сторони [10] (далі - Угода про асоціацію). Згідно з цими документами передбачено провести гармонізацію 
національного законодавства у сфері послуг 3 міжнародних морських перевезень до норм та положень права СС.

Така стратегія повинна прийматися разом 3 планом заходів 3 імплементації положень директив та регламентів ЄС у сфері міжнародного морського та внутрішнього водного транспорту [11] (далі - план заходів), який би враховував усі необхідні заходи для імплементації до законодавства України положень зазначених документів ЄС. Мета такої стратегії також передбачає поетапне виконання положень, які зазначені в Плані заходів[12].

Держава Україна узгоджує своє національне законодавство в межах, які б забезпечували лібералізацію та взаємний доступ на ринки України та ЄС, а також руху вантажів та пасажирів морським і внутрішнім водним транспортом (стаття 138 «Наближення законодавства» [10]).

Основними напрямами реалізації такої стратегії повинні стати:

- поглиблення нормотворчої та аналітичної роботи у сфері внутрішнього водного транспорту; відновлення діяльності центрального органу виконавчої влади, покладення на нього функцій 3 організації виконання міжнародних стандартів та імплементації положень директив та регламентів Свропейського Союзу;

- перегляд чинних і розроблення нових законодавчих актів, які регулюють відносини у сферах внутрішнього водного транспорту i торговельного мореплавства;

- підвищення кваліфікації та навчання персоналу підприємств, організацій, органів виконавчої влади та установ у сфері внутрішнього водного і морського транспорту в навчальних закладах країн - членів СС;

- залучення технічної допомоги СС у вигляді фінансових ресурсів та консультацій;

- приведення українських текстів регламентів та директив у відповідність 3 оригіналами.

Мінінфраструктури повинно стати відповідальним органом за проведення моніторингу реалізації такої стратегії та подавати пропозиції Кабінетові Міністрів України стосовно внесення змін плану заходів, а також за організацію обміну інформацією з СС.

Основною перевагою запровадження сучасних i міжнародних правил митного оформлення і контролю якості вантажів у морських портах України $\epsilon$ скорочення кількості документів, які надаються капітаном судна капітану морського порту при заході в акваторію має бути зменшена в 6 разів. 
Співробітниками Державного підприємства «Херсонський морський торговий порт» та Херсонського національного технічного університету підготовлено проект наказу про внесення змін до існуючого Порядку оформлення приходу суден у морський порт, надання дозволу на вихід суден у море та оформлення виходу суден із морського порту. Цей Порядок був затверджений наказом Мінінфраструктури від 27.06.2013 р. № 430 і має ряд істотних недоліків.

Відповідно до проекту змін, замість 23 копій документів, які згідно чинних нормативно-правових документів повинен надавати капітан судна до морського порту, планується надання всього 4-х:

- класифікаційне свідоцтво;

- свідоцтво про реєстрацію;

- міжнародне обмірне свідоцтво;

- міжнародне свідоцтво про вантажну марку.

Також в Порядок пропонується внести зміни у зв'язку з імплементацією директив СС від 20.10.2010 p. № 2010/65/СС «Про формальності 3 надання відомостей про судна, які прибувають та/або відбувають з портів держав-членів ЄС» та від 27.06.2002 р. № 2002/59/СС, яка засновує Систему СС з нагляду за рухом суден та інформування.

Для підвищення конкурентоспроможності морських портів України пропонується:

- скасувати комісійний контроль на борту судна;

- скасувати процедури при переході між портами України;

- скасувати хімічний контроль ізольованого баласту;

- спростити процедуру оформлення яхт;

- скасувати фінансову гарантію доставки вантажу для перевезень внутрішніми водними шляхами.

Для підвищення привабливості морських портів України пропонується:

- мінімізувати контрольні процедури;

- запровадити електронний документообіг;

- забезпечити оформлення контейнерів до завантаження на авто- або залізничний транспорт;

- запровадити автоматизований радіологічний контроль та скасувати екологічну декларацію;

- удосконалити процедури зберігання та дослідження зерна. 
Перевага нового підходу - це скорочення кількості контрольних процедур. Раніше для виконання таких процедур залучалося щонайменше 5 контролюючих органів. Відтепер судновий агент, ще до моменту прибуття судна в порт, матиме всі необхідні для оформлення документи завчасно, що зекономить час і гроші учасників процедур та усуне вплив людського фактору. До того ж контроль судна під час переходу між портами потрібен буде лише у порту відбуття та кінцевому порту прибуття.

Детально результати удосконалення митного оформлення контролю якості вантажів та суден у морських портах України зображено схематично на рис. 1-3.

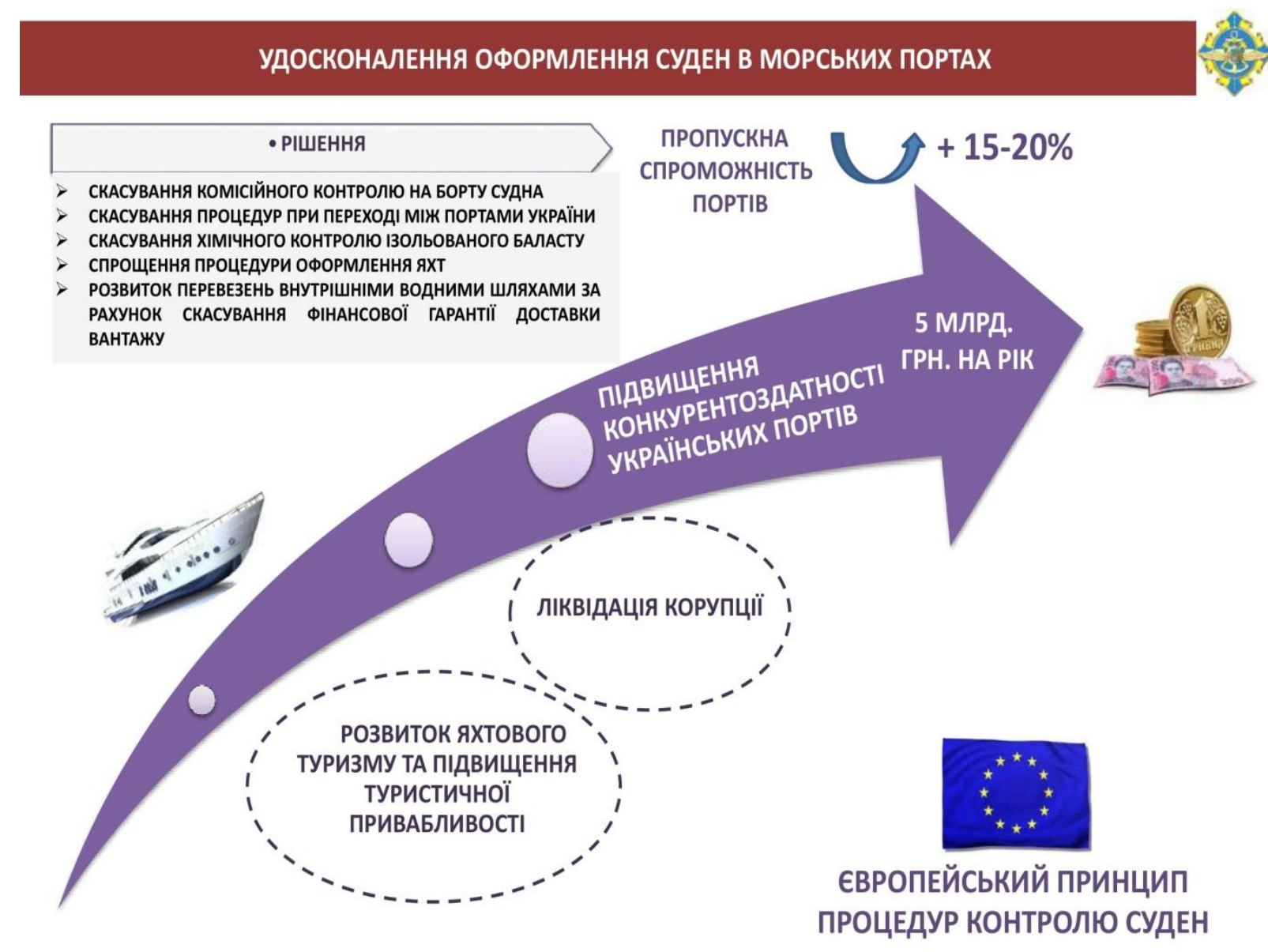

Рис. 1. Схема підвищення конкурентоспроможності морських портів України 
Товарознавчий вісник. - 2021. - Випуск 14.

УДОСКОНАЛЕННЯ ОФОРМЛЕННЯ ВАНТАЖІВ В МОРСЬКИХ ПОРТАХ

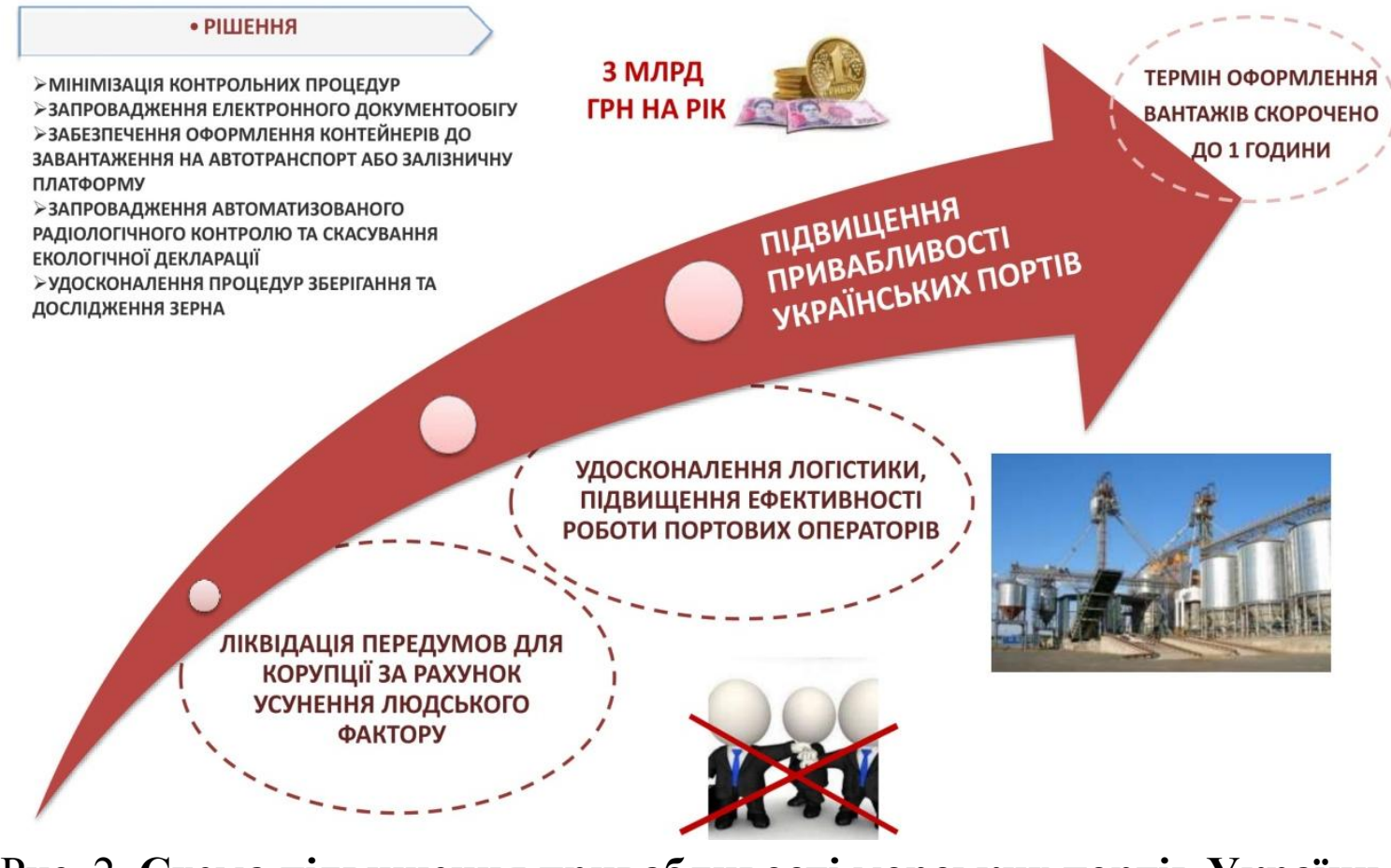

Рис. 2. Схема підвищення привабливості морських портів України

\section{IHШE}

• РІШЕНHЯ

У ДОПОВНЕННЯ ПЕРЕЛІКУ СПЕЦ ПОСЛУГ НОВОю ПОСЛУгою ДОСТУПУ ПОРТОВОГО ОПЕРАТОРА ДО ПРИЧАЛУ ᄀ СПРОЩЕННЯ ПРОЦЕДУРИ ЗАБЕЗПЕЧЕННЯ ПАСПОРТНИХ ГЛИБИН В

ПOPTAX

\section{ЗДЕШЕВШЕННЯ} лОГІСТИКИ

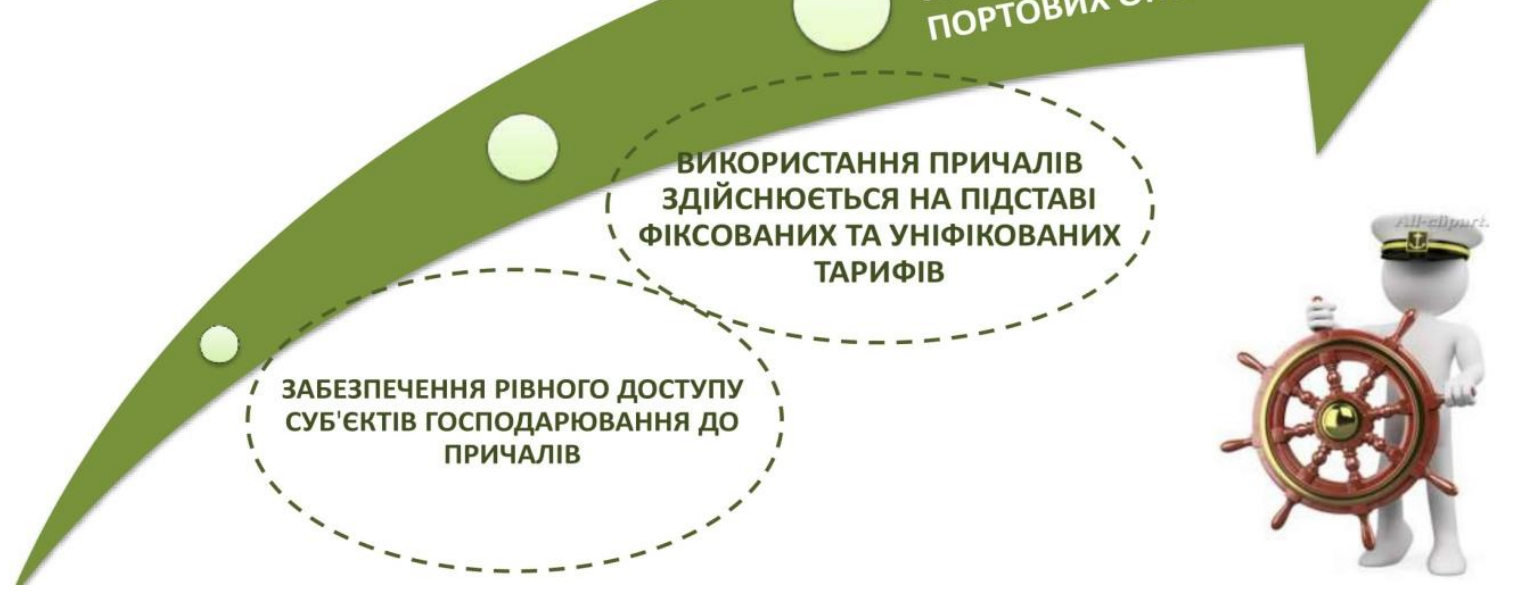

Рис. 3. Схема прогнозування та збалансованості витрат портових операторів в Україні 
Висновки та перспективи подальших досліджень. Основною перевагою запровадження сучасних i міжнародних правил митного оформлення i контролю якості вантажів у морських портах України є скорочення кількості документів. В порядок пропонується внести зміни у зв'язку з імплементацією директив СС від 20.10.2010 р. № 2010/65/СС «Про формальності 3 надання відомостей про судна, які прибувають та/або відбувають 3 портів держав-членів ЄС» та від 27.06.2002 р. № 2002/59/ЄС, яка засновує Систему ЄС з нагляду за рухом суден та інформування.

Пропонується суттєве скорочення кількості контрольних процедур. Такі нововведення до Порядку митного оформлення та контролю якості вантажів відповідно до європейського законодавства скоротять час перебування суден у портах та збільшать пропускну спроможність портів на 15\%. Внаслідок чого скоротиться час неефективного простою, за який раніше доводилося сплачувати вантажовласникам.

\section{Список використаних джерел}

1. Артеменко А. В. Удосконалення нормативно-правового регулювання питань здійснення процедур митного контролю та митного оформлення водних транспортних засобів та товарів, що переміщуються ними через державний кордон України .Митна безпека. 2018. Вип. 2. С. 13-19 .

2. Ломейко Ю. А. Аналіз та напрями вдосконалення взаємовідносин між суб'єктами митного контролю . Бізнес Інформ. 2015. № 2. С. 58-67.

3. Брачук А.О. Досвід США у запровадженні системи «Сдине вікно». Правові та інституційні механізми забезпечення розвитку України в умовах європейської інтеграції: матеріали міжнар. наук.-практ. конф. (м. Одеса, 18 трав. 2018 р.): у 2 т. Т. 1. Одеса : Видав. Дім «Гельветика», 2018. С. $439-442$.

4. Прокопенко В. В. Виконання митних формальностей при переміщенні товарів через митний кордон України різними видами транспорту: монографія. Дніпро: Університет митної справи та фінансів, 2018. $336 \mathrm{c}$.

5. Прокопенко В.В. Митні формальності, пов'язані із здійсненням митного контролю суден закордонного плавання та членів екіпажу. Науковий вісник Херсонського державного університету. Серія «Юридичні науки». 2018. № 2. Т. 1. С. 177-180.

6. Прокопенко В.В. Митні формальності, пов'язані із митним оформленням суден закордонного плавання. Науковий вісник публічного та приватного права. 2018. № 1. Т. 2. С. $35-40$.

7. Про затвердження Порядку виконання митних формальностей при здійсненні транзитних переміщень (із змінами, внесеними згідно з Наказом Міністерства фінансів №305 
від 17.06.2020) [Електронний ресурс]: наказ, виданий Мін. Фін. Укр.: від 9 жовтня 2012 року №1066. - Режим доступу: https://zakon.rada.gov.ua/laws/show/z2120-12

8. Питання пропуску через державний кордон осіб, автомобільних, водних, залізничних та повітряних транспортних засобів перевізників і товарів, що переміщуються ними (із змінами, внесеними згідно з Постановами КМ № 1040 від 04.12.2019) [Електронний ресурс]: постанова, видана Каб. Мін. Укр.: від 21 травня 2012 року №451. - Режим доступу: https://zakon.rada.gov.ua/laws/show/451-2012-п

9. Про затвердження Порядку виконання митних формальностей на морському та річковому транспорті (із змінами, внесеними згідно з Постановами КМ № 522 від 23.05.2017) [Електронний ресурс]: постанова, видана Каб. Мін. Укр.: від 21 травня 2012 року №451. Режим доступу: https://zakon.rada.gov.ua/laws/show/451-2012-п

10. Про схвалення Стратегії імплементації положень директив та регламентів Європейського Союзу у сфері міжнародного морського та внутрішнього водного транспорту («дорожньої карти») [Електронний ресурс]: розпорядження, видане Каб. Мін. Укр.: від 11 жовтня 2017 року №747. - Режим доступу: https://zakon.rada.gov.ua/laws/show/747-2017-p

11. Угода про асоціацію між Україною, з однієї сторони, та Європейським Союзом, Європейським співтовариством 3 атомної енергії і їнніми державами-членами, 3 іншої сторони [Електронний ресурс]: Закон України, ратифікований Верховною Радою: від 16.09.2014 року № 1678-VII. - Режим доступу: https://zakon.rada.gov.ua/laws/show/984_011

12. План заходів 3 імплементації положень директив та регламентів Свропейського Союзу у сфері міжнародного морського та внутрішнього водного транспорту [Електронний ресурс]: розпорядження, видане Каб. Мін. Укр.: від 11 жовтня 2017 року №747-р. - Режим доступу: https://zakon.rada.gov.ua/laws/show/747-2017-p\#n38

13. Про затвердження середньострокового плану пріоритетних дій Уряду до 2020 року та плану пріоритетних дій Уряду на 2017 рік [Електронний ресурс]: розпорядження, видане Каб. Мін. Укр.: від 11 жовтня 2017 року №275. Режим доступу: https://zakon.rada.gov.ua/laws/show/275-2017-p\#n10

Objectives. To formulate possible ways to improve mutual relations arising during the implementation of customs control, and to develop methods for their practical implementation by reducing the number of documents in accordance with international conventions and EU directives based on the analysis of laws and legal documents regulating the implementation of cargo customs control procedures in Ukrainian seaports and their applications.

Methods. Analytical methods of analysis and synthesis, comparative analysis and data generalization from the available studies and regulatory documents were used for the research.

Results. The paper analyzes national legislation adjustment to the EU standards in the field of customs control in seaports. The main challenges of implementing the standards defined in the Association Agreement with the EU and international conventions into national legislation are identified. The paper concludes about the relevance of bringing national legislation into compliance with international shipping standards. Creating a modern legal framework is critical for Ukraine to return to the global marine shipping market and to attract investments in this economic sector. Based on the research results, the promising trends to improve the procedure for 
cargo customs clearance and quality control in Ukrainian seaports are proposed in order to reduce the number of legal documents and boost the process of cargo customs clearance in accordance with international conventions and EU directives. To increase the competitiveness and economic attractiveness of Ukrainian seaports, it is proposed to introduce e-document flow, cancel commission control on board, cancel procedures for cargo traffic via Ukrainian ports, cancel chemical control, simplify radiological and environmental control, cancel financial restrictions and boost procedures.

Scientific novelty. The paper analyzes the state of regulatory and legal support in the area of customs control in seaports. For the first time, a set of practical guidelines for improving the procedure for cargo customs clearance and quality control in Ukrainian seaports has been developed.

Practical implications. Some problematic issues related to the implementation of the standards set in the Ukraine-European Union Association Agreement into national legislation are defined. Draft amendments to the current ship arrival procedures at a seaport have been developed and proposed, in order to improve the existing standards and boost the process of cargo customs clearance.

Стаття рекомендована до друку доктором технічних наук, професором Херсонського національного технічного університету Кузьміной Т.О. Стаття надійшла до редакиії. 23.01.2021 p. 